\title{
UNRAM
}

Matatam Vnlvetsly - Mastet of Management goutenal

\section{IDENTIFIKASI KEBANGKRUTAN DI PERUSAHAAN FARMASI : MODEL ALTMAN Z-SCORE ANALYSIS (STUDI PADA PERUSAHAAN FARMASI YANG TERDAFTAR DI BURSA EFEK INDONESIA PERIODE 2012-2016)}

\section{Totok Haryanto}

Fakultas Ekonomi dan Bisnis Universitas Muhammadiyah Purwokerto (UMP), Indonesia, Email :feb.ump.th@gmail.com

\begin{tabular}{|c|c|}
\hline ARTICLE INFO & ABSTRACT \\
\hline $\begin{array}{l}\text { Keywords : } \\
\text { altman z-score, pharmaceutical } \\
\text { company, bankruptcy, sustainable } \\
\text { Kata kunci : } \\
\text { Altman z-score, perusahaan farmasi, } \\
\text { kebangkrutan, keberlangsungan } \\
\text { How to cite: } \\
\text { Haryanto, T., (2018). Identifikasi } \\
\text { kebangkrutan di perusahaan farmasi: } \\
\text { Model altman z-score analysis (studi } \\
\text { pada perusahaan farmasi yang terdaftar } \\
\text { di bursa efek indonesia periode 2012- } \\
\text { 2016. JMM UNRAM, 7(4), } 1 \text { - } 16 \\
\text { DOI: } \\
\text { 10.29303/jmm.v7i4.342 }\end{array}$ & $\begin{array}{l}\text { Every company has different problems of each type, } \\
\text { including in the categorization of whether the company is } \\
\text { categorized to be bankrupt or not. This study was conducted } \\
\text { to study and detect the possibility of bankruptcy of } \\
\text { pharmaceutical companies in Indonesia using the Altman Z- } \\
\text { Score model. The sample used in this study is a } \\
\text { pharmaceutical company listed on the Indonesia Stock } \\
\text { Exchange (BEI) and the company publishes regular financial } \\
\text { statements in } 2012 \text { until 2016. In the Altman Z-Score } \\
\text { model, grouping companies into three categories ie not } \\
\text { bankrupt, prone to bankruptcy, and bankruptcy. For } \\
\text { companies that fall into the category of bankruptcy, should } \\
\text { be more careful in asset management and corporate policy } \\
\text { making and strive to continue to improve the company's } \\
\text { performance and try to utilize assets owned more effectively } \\
\text { and efficiently, so that will gain a more optimal advantage. } \\
\text { While for companies that are in a healthy condition must } \\
\text { still maintain and improve the performance of the company, } \\
\text { so it will be sustinable and minimize the occurrence of } \\
\text { bankruptcy. } \\
\text { Setiap perusahaan memiliki permasalahan yang berbeda dari } \\
\text { setiap jenisnya, termasuk dalam pengkategorian apakah } \\
\text { perusahaan tersebut dikatakan bangkrut ataukah tidak. } \\
\text { Penelitian ini dilakukan untuk mempelajari dan mendeteksi } \\
\text { kemungkinan terjadinya kebangkrutan perusahaan farmasi } \\
\text { yang ada di Indonesia dengan menggunakan hitungan } \\
\text { model Altman Z-Score. Sampel yang digunakan dalam } \\
\text { penelitian ini adalah perusahaan farmasi yang terdaftar di } \\
\text { Bursa Efek Indonesia (BEI) dan perusahaan tersebut } \\
\text { menerbitkan laporan keuangan secara teratur pada tahun } \\
\text { 2012 sampai dengan tahun 2016. Dalam model Altman Z- } \\
\text { Score, mengelompokkan perusahaan menjadi tiga kategori } \\
\text { yaitu tidak bangkrut, rawan bangkrut, dan bangkrut. Bagi }\end{array}$ \\
\hline
\end{tabular}

jmm.unram.ac.id 


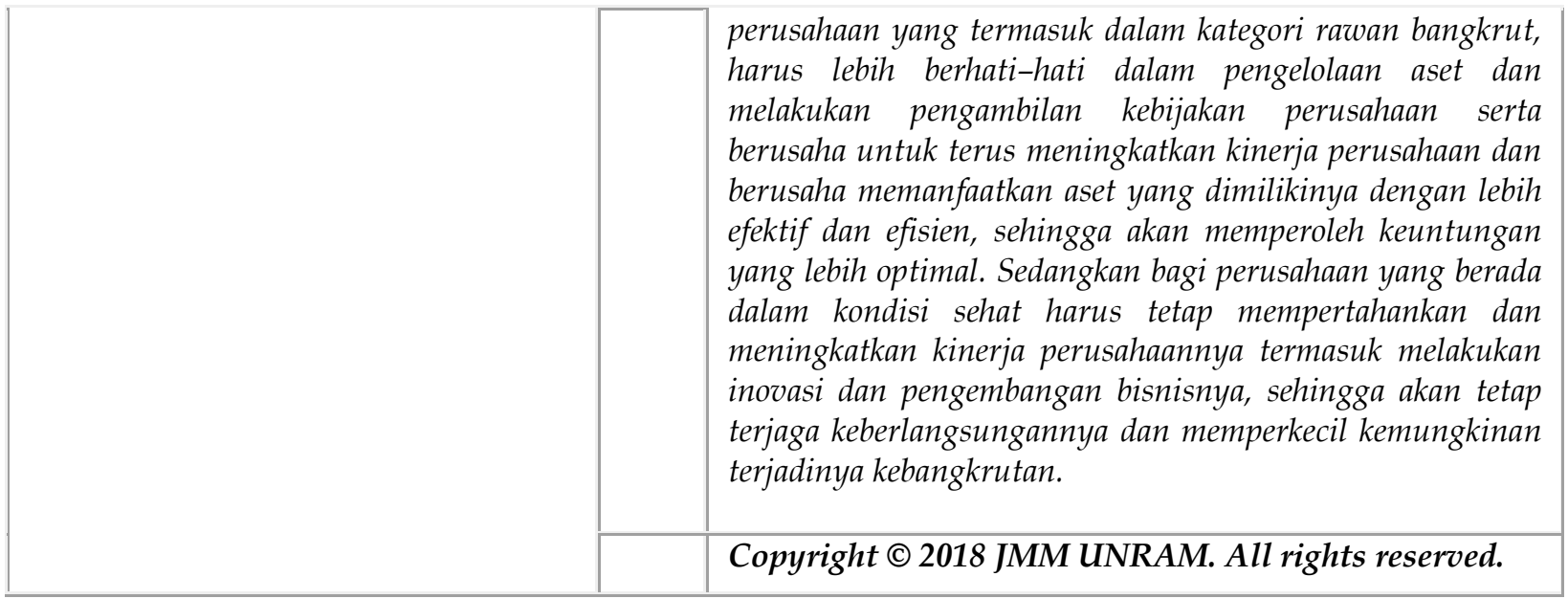

\section{PENDAHULUAN}

Bisnis farmasi atau obat-obatan merupakan salah satu usaha dengan produk yang selalu dibutuhkan masyarakat. Gabungan Pengusaha (GP) Farmasi masih optimis memandang bisnis obat di 2018 ini. Meski tahun ini masih bakal dipenuhi tantangan layaknya tahun 2017. Jika di tahun-tahun sebelumnya industri farmasi bisa menikmati pertumbuhan bisnisnya dobel digit, kisaran $10-15 \%$ setiap tahunnya, sekarang raihan tersebut masih sulit dikejar. Setidaknya ada dua persoalan yang bakal dihadapi pelaku bisnis farmasi tahun 2018 ini. Pertama soal peraturan proteksi lingkungan yang dilakukan pemerintah China menekan produksi bahan baku obat. Kedua, karena bahan baku banyak yang impor dari China, mata uang yuan yang menguat terhadap dollar AS mempengaruhi harga bahan baku tersebut.

Berikut adalah beberapa update informasi mengenai perkembangan bisnis farmasi di Indonesia. Misalnya, PT Merck Indonesia, Tbk melakukan ekspansi pabrik dengan menambah fasilitas produksi tablet dan kapsul. PT Merck Indonesia menargetkan pada 2018 kapasitas produksi menjadi dua kali lipat. Kapasitas produksi perusahaan saat ini mencapai 900 juta tablet dan kapsul per tahun dengan utilisasi $77 \%$ atau sebesar 700 juta tablet dan kapsul pada 2015. Ekspansi tersebut akan dibagi menjadi empat tahap. Pada 2015 ekspansi dimulai dengan menambah kapasitas infrastruktur berupa fasilitas pembuatan produk solid atau tablet dan kapsul, dilanjutkan pada tahun ini hingga 2017 dengan penambahan fasilitas mesin. Pada 2018 perusahaan akan menambah kapasitas pada produk obat cair.

Dari berbagai permasalahan yang dihadapi oleh beberapa perusahaan farmasi yang berbeda tipe dan kepentingan tersebut, maka perusahaan harus lebih mampu untuk mengantisipasi kemungkinan adanya kesalahan yang akan berdampak buruk bagi perusahaan. Bagi perusahaan farmasi yang tidak mempunyai kemampuan dalam mempersiapkan diri untuk menghadapi keadaan tersebut maka dapat dimungkinkan akan mengalami penurunan kinerja yang berdampak pada terjadinya kebangkrutan.

Persaingan dalam dunia bisnis semakin ketat dengan adanya keunggulan yang dimiliki oleh setiap perusahaan. Keunggulan kompetitif adalah jantung dari kinerja perusahaan dalam pasar yang kompetitif. Keunggulan kompetitif adalah tentang bagaimana sebuah perusahaan benar-benar menempatkan strategi-strategi generik ke dalam praktik." (Porter, 2008). Salah satu hal yang terkait dengan keunggulan kompetitif adalah bagaimana biaya tersebut dapat diefisienkan namun tetap menjaga performa bisnis. Keunggulan kompetitif bertumbuh secara fundamental dari nilai yang memungkinkan perusahaan untuk menciptakan nilai itu bagi para pembelinya melebihi biaya yang dikeluarkan perusahaan untuk menciptakannya.

Salah satu aspek penting dalam memenangkan persaingan di dunia bisnis adalah 
kinerja perusahaan, dan salah satunya adalah aspek keuangan. Kinerja keuangan yang buruk dan tidak akurat akan menjadi penghambat kinerja perusahaan untuk meningkatkan produktivitas. Jika permasalahan tersebut tidak segera diatasi maka perusahaan tersebut bisa teridentifikasi akan mengalami kebangkrutan. Kebangkrutan suatu usaha dapat dilihat dan diukur melalui profil keuangan perusahaan dengan cara menganalisis laporan keuangan. Instrumen yang paling umum digunakan dalam menganalisis kinerja keuangan adalah analisis rasio keuangan.

Analisis terhadap peluang kebangkrutan suatu perusahaan dipandang penting bagi suatu perusahaan. Analisis ini tidak hanya diperuntukkan bagi perusahaan yang sehat saja melainkan untuk perusahaan-perusahaan yang dianggap kurang sehat. Analisis ini dilakukan sebagai tindakan preventif bagi perusahaan yang sehat dan merupakan tindakan kuratif bagi perusahaan yang tidak sehat. Dalam penelitiannya, Edward I. Altman, setelah menyeleksi 22 rasio keuangan, Altman menentukan lima rasio keuangan yang dapat digunakan untuk mendeteksi kebangkrutan perusahaan beberapa saat sebelum perusahaan tersebut dinyatakan bangkrut. Kelima rasio tersebut adalah: modal kerja terhadap aktiva, laba ditahan terhadap total aktiva, laba sebelum bunga dan pajak terhadap aktiva, nilai pasar modal saham terhadap nilai buku hutang, dan penjualan terhadap aktiva. Analisis tersebut dikenal dengan analisis Z-Score yang dapat memprediksi secara akurat tentang kinerja perusahaan dari aspek keuangan, serta kemungkinan kondisi kesehatan keuangan di masa yang akan datang, apakah perusahaan mengalami kebangkrutan, rawan bangkrut, atau dalam keadaan sehat. Hal tersebut sangat membantu bagi para investor dalam menanamkan modalnya pada perusahaan yang bersangkutan. Dan bagi para pemilik atau pimpinan perusahaan, mereka mempunyai kepentingan untuk dapat menyusun, mempertimbangkan, dan memperbaiki serta menentukan keputusan yang tepat agar dapat dipertanggung jawabkan kepada para pemegang saham atau investor.

Berdasarkan uraian latar belakang diatas dapat ditentukan rumusan masalah dalam penelitian ini, yaitu bagaimana mengidentifikasi perusahaan farmasi apakah termasuk dalam kondisi yang berpotensi mengalami kebangkrutan atau tidak dengan menggunakan analisis model Altman z-score. Sekaligus diharapkan bahwa dengan adanya penelitian ini, akan memberikan kahzanah baru terkait dengan update informasi mengenai bagaimana melihat secara umum dan terstruktur bagaimana perusahaan tersebut mengalami kondisi yang sehat ataupun tidak sehat.

\section{TINJAUAN TEORITIS}

Menurut Undang-Undang Kepailitan dan Penundaan Kewajiban Pembayaran Utang, UU No. 37 Tahun 2004, Lembaran Negara No. 131 Tahun 2004. Tambahan Lembaran Negara No. 4443. Pasal 1 nomor 1 Undang- Undang Nomor 37 Tahun 2004 tentang Kepailitan dan Penundaan Kewajiban Pembayaran Utang, kepailitan adalah sita umum atas semua kekayaan Debitor Pailit yang pengurusannya dilakukan oleh Kurator di bawah pengawasan Hakim Pengawas sebagaimana diatur dalam undang-undang tersebut.

Sedangkan istilah 'bangkrut' tidak dikenal dalam undang-undang negara kita, sehingga tidak adanya kepastian mengenai definisi bangkrut itu sendiri. Namun, kata bangkrut diadopsi dari bahasa Inggris yaitu bankruptcy, yang berarti kebangkrutan.

\subsection{Definisi Kebangkrutan}

Kebangkrutan (bankruptcy) biasanya diartikan sebagai kegagalan perusahaan dalam menjalankan operasi perusahaan untuk menghasilkan laba. Pengertian kebangkrutan juga dapat dilihat dari pendekatan aliran dan pendekatan stok (Hanafi, 2008). Jika dilihat dari pendekatan aliran, perusahaan akan dinyatakan dalam keadaan bangkrut jika tidak bisa 
menghasilkan cash flow yang cukup. Dari sudut pandang stok, perusahaan dinyatakan bangkrut meskipun perusahaan masih dapat menghasilkan aliran kas yang cukup, atau mempunyai prospek yang baik di masa mendatang.

Menurut Brigham (2014) kebangkrutan perusahaan adalah suatu kegagalan yang terjadi pada perusahaan yang bisa diartikan dengan:

1. Economic Distressed, yaitu kondisi perusahaan kehilangan uang atau pendapatan perusahaan tidak mampu menutupi biayanya sendiri, artinya ini tingkat labanya lebih kecil dari biaya modal atau nilai sekarang dari arus kas perusahaan lebih kecil dari kewajiban. Kegagalan terjadi bila arus kas sebenarnya dari perusahaan tersebut jauh di bawah arus kas yang diharapkan.

2. Financial Distressed, yaitu kondisi perusahaan yang mana kesulitan dana baik dalam arti dana didalam pengertian kas atau dalam pengertian modal kerja. Sebagian asset liabilty management sangat berperan dalam pengaturan untuk menjaga agar tidak terkena kegagalan keuangan. Kegagalan keuangan dapat diartikan juga sebagai insolvensi yang membedakan antara dasar arus kas dan dasar saham.

Toto (2011:332) memberikan pengertian tentang kebangkrutan perusahaan (bankruptcy), yaitu kondisi dimana perusahaan tidak mampu lagi untuk melunasi kewajibannya. Kondisi ini biasanya tidak muncul begitu saja di perusahaan, ada indikasi awal dari perusahaan tersebut yang biasanya dapat dikenal lebih dini kalau laporan keuangan dianalisis secara lebih cermat dengan suatu cara tertentu. Rasio keuangan dapat digunakan sebagai indikasi adanya kebangkrutan di perusahaan.

\subsection{Faktor-Faktor Penyebab terjadinya Kebangkrutan}

Menurut Sartono (2012), terdapat tiga faktor penyebab terjadinya kebangkrutan di perusahaan, yaitu:

1. Perusahaan yang menghadapi technically insolvent, jika perusahaan tidak dapat memenuhi kewajibannya yang segera jatuh tempo tetapi asset perusahaan nilainya lebih tinggi daripada hutangnya.

2. Perusahaan yang menghadapi legally insolvent, jika nilai asset perusahaan lebih rendah daripada nilai utang perusahaan.

3. Perusahaan yang menghadapi kebangkrutan yaitu jika tidak dapat membayar utangnya dan oleh pengadilan dinyatakan pailit.

Menurut Reny $(2011,28)$, faktor-faktor penyebab kebangkrutan perusahaan adalah sebagai berikut:

1. Faktor Ekonomi

Gejala inflasi dan deflasi dalam harga barang dan jasa, kebijakan keuangan, suku bunga dan devaluasi uang dalam hubungannya dengan uang asing serta neraca pembayaran, surplus dalam hubungannya dengan perdagangan luar negeri, merupakan faktor-faktor ekonomi yang dapat menjadi penyebab terjadinya kebangkrutan. Hal ini dikarenakan ketidaksiapan perusahaan dalam melakukan langkah antisipasi dalam permasalahan tersebut, khususnya dari aspek keuangan.

2. Faktor Sosial

Perubahan gaya hidup masyarakat yang mempengaruhi permintaan terhadap produk dan jasa ataupun cara perusahaan berhubungan dengan karyawan. Hal ini akan berdampak pada perilaku konsumen yang secara langsung maupun tidak akan berpengaruh terhadap permintaan produk.

3. Faktor Teknologi

Semakin tingginya tingkat penggunaan tehnologi dalam aspek operasional perusahaan, menyebabkan biaya yang ditanggung perusahaan mengalami kenaikan terutama untuk 
pemeliharaan dan implementasi yang tidak terencana, sistemnya tidak terpadu dan para manajer pengguna kurang profesional.

4. Faktor Pemerintah

Kebijakan pemerintah terhadap pencabutan subsidi pada perusahaan dan industri, pengenaan tarif ekspor dan impor barang yang berubah, kebijakan undang-undang baru bagi perbankan atau tenaga kerja dan lain-lain.

5. Faktor Pelanggan

Perusahaan harus mengidentifikasi sifat konsumen, untuk menghindari kehilangan konsumen, juga untuk menciptakan peluang, menemukan konsumen baru dan menghindari menurunnya hasil penjualan dan mencegah konsumen berpaling ke pesaing.

6. Faktor Pemasok

Perusahaan dan pemasok harus tetap bekerjasama dengan baik karena kekuatan pemasok untuk menaikkan harga dan mengurangi keuntungan pembelinya tergantung pada seberapa besar pemasok ini berhubungan dengan perdagangan bebas.

7. Faktor Pesaing

Pesaing merupakan faktor yang sangat berpengaruh terhadap keberlangsungan perusahaan. Jika perusahaan kalah bersaing, maka perusahaan akan kehilangan konsumen dan hal tersebut akan berakibat menurunnya pendapatan perusahaan.

\subsection{Manfaat Informasi Kebangkrutan}

Informasi kebangkrutan sangat bermanfaat bagi stakeholder (Rudianto, 2013:253), berikut adalah pihak-pihak yang memperoleh manfaat dari informasi tersebut:

1. Manajemen Perusahaan

Apabila manajemen perusahaan bisa mendeteksi kemungkinan terjadinya kebangkrutan lebih awal, maka tindakan pencegahan bisa lakukan, bisa berupa merger atau restrukturisasi keuangan.

2. Pemberi Pinjaman (Kreditor)

Informasi kebangkrutan perusahaan bisa bermanfaat bagi sebuah badan usaha yang berposisi sebagai kreditor untuk mengambil keputusan mengenai diberikan-tidaknya pinjaman kepada perusahaan tersebut.

3. Investor

Informasi kebangkrutan perusahaan bisa bermanfaat bagi sebuah usaha yang berposisi sebagai investor perusahaan lain. Jika perusahaan investor berniat membeli saham atau obligasi yang dikeluarkan oleh suatu perusahaan yang telah dideteksi kemungkinan kebangkrutannya, maka perusahaan calon investor itu dapat memutuskan membeli atau tidak surat berharga yang dikeluarkan perusahaan tersebut.

4. Pemerintah

Pada beberapa sektor usaha, lembaga pemerintah bertanggung jawab mengawasi jalannya usaha tersebut. Pemerintah juga mempunyai badan usaha yang harus selalu diawasi. Lembaga pemerintah mempunyai kepentingan untuk melihat tanda-tanda kebangkrutan lebih awal supaya tindakan yang perlu bisa dilakukan lebih awal.

5. Akuntan Publik

Akuntan publik perlu menilai potensi kebangkrutan hidup badan usaha yang sedang diauditnya, karena akuntan akan menilai kemampuan going concern perusahaan tersebut.

\subsection{Analisis Altman Z-Score}

Model Altman z-score merupakan alat analisis untuk mengukur ada tidaknya potensi kebangkrutan suatu perusahaan. Analisis ini bersifat prediktif dengan menggunakan 
rasio keuangan. Sejumlah studi telah dilakukan untuk mengetahui kegunaan analisis rasio keuangan dalam memprediksi kegagalan atau kebangkrutan suatu perusahaan. Salah satu studi tentang prediksi ini adalah multiple discriminant analysis (MDA) yang biasa disebut metode Z-Score model Altman. Dengan menggunakan analisis Z-Score juga dapat digunakan untuk menunjukkan kinerja perusahaan yang sekaligus merefleksikan prospek perusahaan di masa yang akan datang. Formula analisis model Altman $z$-score adalah sebagai berikut:

Dimana:

$$
Z=1,2(X 1)+1,4(X 2)+3,3(X 3)+0,6(X 4)+1(X 4)
$$

X1 $\rightarrow$ WCTA
X2 $\rightarrow$ RETA
X3 $\rightarrow$ EBITTA
X4 $\rightarrow$ MVEBVL
X5 $\rightarrow$ STA

$$
\begin{aligned}
& =(\text { Aktiva lancar-Utang Lancar) dibagiTotal Aktiva } \\
& =\text { Laba yang ditahan dibagi Total Aktiva } \\
& =\text { Laba sebelum bunga dan pajak dibagi Total Aktiva } \\
& =\text { Nilai pasar modal dibagi Nilai buku hutang } \\
& =\text { Penjualan dibagi Total aktiva }
\end{aligned}
$$

\subsection{Rasio-Rasio Model Altman Z-Score}

Rasio-rasio yang dikembangkan dalam model Altman Z-Score adalah sebagai berikut: WCTA= Working Capital to Total Asset (Rasio Modal Kerja terhadap Total Aktiva)

Rasio ini digunakan untuk mengukur tingkat likuiditas perusahaan. Aktiva likuid bersih atau modal kerja bersih adalah selisih antara total aktiva lancar dikurangi total kewajiban lancar. Secara umum, jika perusahaan mengalami kesulitan keuangan, modal kerja akan turun lebih cepat daripada total aktiva menyebabkan rasio ini turun. Modal kerja bersih yang negative juga kemungkinan besar akan menghadapi masalah dalam menutupi kewajiban jangka pendeknya karena tidak tersedianya aktiva lancar yang cukup untuk menutupi kewajiban tesebut. Sebaliknya, perusahaan dengan modal kerja yang bernilai positive jarang sekali menghadapi kesulitan dalam melunasi kewajibannya. Rasio modal kerja menunjukkan jumlah modal kerja yang dimiliki pada setiap Rp 1,00 aktiva perusahaan yang dikeluarkan.

RETA= Retained Earning to Total Assets (Rasio Laba Ditahan terhadap Total Aktiva)

Retained Earning dibagi dengan Total Assets (X2) merupakan rasio profitabilitas yang menilai kemampuan perusahaan dalam menghasilkan laba selama perusahaan beroperasi. Jangka waktu operasi (umur) perusahaan berpengaruh terhadap rasio tersebut karena semakin lama perusahaan beroperasi, memungkinkan untuk memperlancar akumulasi laba ditahan. Hal tersebut menyebabkan perusahaan yang masih relatif muda pada umumnya akan menunjukkan hasil rasio yang rendah, kecuali yang labanya sangat besar pada masa awal berdirinya. Semakin besar rasio ini, menunjukkan semakin besarnya peranan laba ditahan dalam membentuk dana perusahaan. Semakin kecil rasio ini menunjukkan kondisi keuangan perusahaan yang tidak sehat. Rasio laba ditahan terhadap total aktiva menunjukkan bahwa setiap Rp 1,00 aktiva perusahaan dijamin oleh saldo laba ditahan.

EBITTA= Earning Before Interest and Taxes to Total Assets (Rasio EBIT terhadap Total Aktiva)

Rasio ini digunakan untuk mengukur kemampuan perusahaan dalam menghasilkan laba, yaitu tingkat pengembalian aktiva, yang dihitung dengan membagi laba sebelum bunga dan pajak (EBIT) tahunan perusahaan dengan total aktiva pada neraca akhir tahun. Rasio ini juga dapat digunakan sebagai indikator seberapa besar produktivitas penggunaan dana yang dipinjam oleh perusahaan. Rasio EBIT terhadap total aktiva menunjukkan laba bersih sebelum bunga dan pajak yang dapat dihasilkan dari setiap $R p$ 1,00 aktiva perusahaan.

MVEBVL= Market Value Of Equity to Book Value Of Liabilities (Rasio Nilai Pasar Modal terhadap Total Hutang)

Rasio ini digunakan untuk menunjukkan kemampuan perusahaan dalam memenuhi 
kewajiban-kewajiban jangka panjang dari nilai modal sendiri (saham biasa). Nilai pasar modal sendiri diperoleh dengan mengalikan jumlah lembar saham biasa yang beredar dengan harga pasar per lembar saham biasa. Nilai buku hutang diperoleh dengan menjumlahkan kewajiban lancar dengan kewajiban jangka panjang. Semakin kecil rasio ini, menunjukkan kondisi keuangan peusahaan yang tidak sehat. Rasio nilai pasar modal sendiri terhadap nilai buku total kewajiban menunjukkan setiap $\operatorname{Rp} 1,00$ dari total kewajiban digunakan untuk membiayai modal saham.

STA= Sales to Total Assets (Rasio Penjualan terhadap Total Aktiva)

Rasio ini digunakan untuk mengukur kemampuan perusahaan dalam meningkatkan volume penjualan. Rasio ini merefleksikan adanya efisiensi manajemen dalam menggunakan keseluruhan aktiva perusahaan untuk menghasilkan penjualan dan mendapatkan laba. Semakin rendah rasio ini menunjukkan semakin rendah tingkat pendapatan perusahaan, sehingga menunjukkan kondisi keuangan perusahaan yang tidak sehat. Rasio penjualan terhadap total aktiva menunjukkan efektifitas penggunaan seluruh aktiva perusahaan dalam rangka menghasilkan penjualan bersih yang dapat dihasilkan oleh setiap Rp 1,00 yang diinvestasikan dalam bentuk aktiva perusahaan.

\subsection{Kriteria Altman Z-Score}

Berikut adalah kriteria yang digunakan untuk memprediksi kebangkrutan perusahaan dengan model Altman z-score (Hanafi dan Halim, 2008):

1. Perusahaan yang mempunyai $z$-score $>2,99$ diklasifikasikan sebagai perusahaan sehat.

2. Perusahaan yang mempunyai $z$-score $<1,81$ diklasifikasikan sebagai perusahaan potensial bangkrut.

3. Perusahaan yang mempunyai $z$-score antara 1,81 sampai 2,99 diklasifikasikan sebagai perusahaan pada daerah rawan bangkrut.

\subsection{Penelitian Terdahulu}

1. Rico Chrisnawan dan Norita (2017)

\begin{tabular}{|l|l|}
\hline Judul Penelitian & $\begin{array}{l}\text { Analisis Prediksi Kebangkrutan Menggunakan Metode } \\
\text { Altman Z-Score, Grover Dan Fulmer Pada Industri Sub Sektor } \\
\text { Perkebunan Yang Terdaftar Di Bursa Efek Indonesia } \\
\text { (Studi Kasus Perusahaan Perkebunan Kelapa Sawit Periode } \\
\text { 2011-2015 ) }\end{array}$ \\
\hline Tujuan Penelitian & $\begin{array}{l}\text { Menganalisis prediksi kebangkrutan pada industri sub- } \\
\text { sektor perkebunan kelapa sawit (CPO) }\end{array}$ \\
\hline Perusahaan yang diteliti & Industri Sub Sektor Kelapa Sawit (CPO) \\
\hline $\begin{array}{l}\text { Periode laporan tahunan } \\
\text { perusahaan yang diteliti }\end{array}$ & 2011 - 2015 \\
\hline Hasil & $\begin{array}{l}\text { Terdapat perbedaan yang signifikan antara Altman dengan } \\
\text { Grover, Altman dengan Fulmer, dan Grover dengan Fulmer } \\
\text { pada periode 2011-2015 }\end{array}$ \\
\hline
\end{tabular}

2. Anandasayanan.S dan Subramaniam V.A (2017)

\begin{tabular}{|l|l|}
\hline Judul Penelitian & $\begin{array}{l}\text { Predicting Bankruptcy Of Selected Manufacturing Companies } \\
\text { Listed In Colombo Stock Exchange: Applying Altman's Z-Score }\end{array}$ \\
\hline Tujuan Penelitian & $\begin{array}{l}\text { Menganalisis prediksi kebangkrutan perusahaan } \\
\text { manufaktur terpilih selama 5 tahun terakhir mulai } 2010 \\
\text { sampai 2014 yang terdaftar di Bursa Efek Colombo }\end{array}$ \\
\hline Perusahaan yang diteliti & 7 Manufacturing Company \\
\hline
\end{tabular}




\begin{tabular}{|l|l|}
\hline $\begin{array}{l}\text { Periode laporan tahunan } \\
\text { perusahaan yang diteliti }\end{array}$ & $2010-2014$ \\
\hline Hasil & $\begin{array}{l}\text { Studi tersebut mengungkapkan bahwa empat perusahaan } \\
\text { benar-benar termasuk dalam Zona Aman untuk } \\
\text { keseluruhan periode studi. Tiga perusahaan berada di Zona } \\
\text { Distress yang dengan jelas menunjukkan bahwa } \\
\text { perusahaan-perusahaan ini mungkin akan bangkrut dalam } \\
\text { waktu dekat. }\end{array}$ \\
\hline
\end{tabular}

3. Katarina Intan Afni Patunrui (2017)

\begin{tabular}{|l|l|}
\hline Judul Penelitian & $\begin{array}{l}\text { Analisis Penilaian Financial Distress Menggunakan Model } \\
\text { Altman (Z-Score) Pada Perusahaan Farmasi Yang Terdaftar } \\
\text { di Bursa Efek Indonesia Periode 2013-2015 }\end{array}$ \\
\hline Tujuan Penelitian & $\begin{array}{l}\text { Untuk mengetahui penilaian financial distress terhadap } \\
\text { perusahaan farmasi yang terdaftar di Bursa Efek Indonesia } \\
\text { (BEI) dengan menggunakan model Altman Z-Score. }\end{array}$ \\
\hline Perusahaan yang diteliti & 10 Perusahaan Farmasi \\
\hline $\begin{array}{l}\text { Periode laporan tahunan } \\
\text { perusahaan yang diteliti }\end{array}$ & 2013 - 2015 \\
\hline Hasil & $\begin{array}{l}\text { Hasilnya menunjukkan bahwa model Altman Z-Score dapat } \\
\text { diimplementasikan dalam mendeteksi kemungkinan } \\
\text { financial distress pada perusahaan farmasi. }\end{array}$ \\
\hline
\end{tabular}

4. S.Christina Sheela dan K. Karthikeyan (2012)

\begin{tabular}{|c|c|}
\hline Judul Penelitian & $\begin{array}{l}\text { Evaluating Financial Health Of Pharmaceutical Industry In India } \\
\text { Through 'Z' Score Model }\end{array}$ \\
\hline Tujuan Penelitian & $\begin{array}{l}\text { Untuk memprediksi kesehatan keuangan INDUSTRI } \\
\text { FARMASI dengan referensi khusus ke laboratorium Cipla, } \\
\text { Dr.Reddy dan Ranbaxy Laboratories Ltd dengan } \\
\text { menggunakan model Altman's Z-Score. }\end{array}$ \\
\hline Perusahaan yang diteliti & Perusahaan Farmasi \\
\hline $\begin{array}{l}\text { Periode laporan tahunan } \\
\text { perusahaan yang diteliti }\end{array}$ & $2001-2011$ \\
\hline Hasil & $\begin{array}{l}\text { Diketahui bahwa Cipla dan Dr. Reddy berada di Zona } \\
\text { yang sangat sehat dimana ia berhasil dalam kinerja } \\
\text { keuangannya dan tidak bangkrut. Tapi Ranbaxy berada } \\
\text { dalam zona sehat dimana kelayakan finansialnya } \\
\text { dianggap sehat dan kegagalan dalam situasi tersebut tidak } \\
\text { pasti diprediksi. }\end{array}$ \\
\hline
\end{tabular}

\section{METODE PENELITIAN}

Berikut adalah penjelasan jenis penelitian, populasi dan sampel yang akan digunakan dalam penelitian. Selain itu, dalam bab ini akan dijelaskan mengenai tehnik pengambilan sampel, variabel-variabelnya, dan tehnik analisis data dalam penelitian. 


\subsection{Jenis Penelitian}

Jenis penelitian ini adalah penelitian diskriptif dengan pendekatan kuantitatif, yaitu penelitian yang dilakukan untuk mengumpulkan informasi terkait dengan suatu fenomena atau gejala yang terjadi, yaitu gejala menurut apa adanya saat dilakukan penelitian (Arikunto, 2007).

\subsection{Populasi dan Sampel Penelitian}

Populasi yang digunakan dalam penelitian ini adalah perusahaan farmasi yang terdaftar di Bursa Efek Indonesia (BEI). Sampel atau obyek yang digunakan dalam penelitian ini adalah laporan keuangan tahunan dari 9 perusahaan farmasi di Indonesia pada periode 2012 - 2016, yang diunduh dari www.idx.co.id, yang terdiri dari PT. Indofarma (Persero), Tbk, PT. Darya-Varia Laboratoria, Tbk, PT. Kimia Farma (Persero), Tbk, PT. Kalbe Farma, Tbk, PT. Merck Indonesia,Tbk, PT. Pyridam Farma, Tbk, PT. Merck Sharp Dohme Pharma, Tbk, PT. Industri Jamu dan Farmasi Sido Muncul, Tbk, dan PT. Tempo Scan Pasific, Tbk.

\subsection{Teknik Pengambilan Sampel}

Tehnik pengambilan sampel yang digunakan dalam penelitian ini adalah purposive sampling, yaitu teknik sampling dengan mengambil sampel dari suatu populasi yang luas yang kemudian disederhanakan dengan suatu kriteria tertentu (Sugiyono, 2010). Kriteriakriteria pengambilan sampel yang dipergunakan dalam penelian ini adalah sebagai berikut :

1. Sampel penelitian merupakan perusahaan farmasi yang sudah go public dan terdaftar di Bursa Efek Indonesia (BEI).

2. Sampel penelitian diambil dari laporan tahunan dari masing-masing perusahaan dari tahun 2012 sampai dengan 2016.

\subsection{Variabel dan Definisi Operasional Variabel}

Definisi operasional merupakan penentuan construct sehingga menjadi sebuah variabel yang terukur. Sehingga variabel yang telah diidentifikasi perlu didefinisikan agar dapat dianalisis dan diukur besarnya. Berikut adalah definisi operasional dari model Altmant Z-Score (Hanafi, 2014: 656):

Dalam penelitian ini, variabel-variabel yang akan diamati adalah sebagai berikut:

1. WCTA= Working Capital to Total Asset (X1)

Rasio ini merupakan rasio likuiditas yang menunjukkan kemampuan perusahaan dalam memenuhi kewajiban jangka pendeknya. Modal kerja bersih adalah selisih antara total aktiva lancar dikurangi total kewajiban lancar.

Berikut rumus dari rasio WCTA :

$\mathbf{X} \mathbf{1} \rightarrow \mathbf{W C T A}=($ Aktiva lancar-Utang Lancar $)$ :Total Aktiva

2. RETA= Retained Earning to Total Assets (X2)

Rasio ini merupakan rasio profitabilitas yang menunjukkan kemampuan perusahaan untuk menghasilkan laba ditahan dan total aktiva peruasahaan. Semakin besar rasio ini, menunjukkan semakin besarnya peranan laba ditahan dalam membentuk dana perusahaan. Semakn kecil rasio ini menunjukkan keuangan perusahaan yang tidak sehat. Berikut rumus dari rasio RETA :

X2 $\rightarrow$ RETA= Laba yang ditahan : Total Aktiva

3. EBITTA= Earning Before Interest and Taxes to Total Assets (X3)

Rasio ini menunjukkan kemampuan perusahaan untuk menghasilkan laba dari aktiva perusahaan, sebelum pembayaran bunga dan pajak. Semakin rendah rasio ini menunjukkan semakin kecil kemampuan perusahaan dalam menghasilkan laba sebelum bunga dan pajak dari aktiva yang digunakan sehingga menunjukkan kondisi keuangan 
yang tidak sehat.

Berikut rumus dari rasio EBITTA:

X3 $\rightarrow$ EBITTA = Laba sebelum bunga dan pajak : Total Aktiva

4. MVEBVL= Market Value Of Equity to Book Value Of Liabilities (X4)

Rasio ini menunjukkan kemampuan perusahaan untuk memenuhi kewajiban- kewajiban jangka panjang dari nilai modal sendiri. Nilai pasar modal sendiri diperoleh dengan mengalikan jumlah lembar saham biasa yang beredar dengan harga penutupan pasar per lembar saham biasa. Nilai buku hutang diperoleh dengan menjumlahkan kewajiban lancar dengan kewajiban jangka panjang. Semakin kecil rasio ini, menunjukkan kondisi keuangan perusahaan yang tidak sehat.

Berikut rumus dari rasio MVEBVL:

X4 $\rightarrow$ MVEBVL $=$ Nilai pasar modal $:$ Nilai buku hutang

5. $S T A=$ Sales to Total Assets (X5)

Rasio ini merupakan rasio aktivitas yang digunakan untuk mengukur kemampuan perusahaan dalam dalam meningkatkan volume penjualan. Semakin rendah rasio ini menunjukkan semakin rendah tingkat pendapatan perusahaan, sehingga menunjukkan kondisi keuangan perusahaan yang tidak sehat.

Rumus dari rasio ini adalah:

X5 $\rightarrow$ STA $=$ Penjualan $:$ Total aktiva

\section{Nilai Z-Score}

Mengklasifikasikan masing-masing sampel penelitian berdasarkan kriteria-kriteria kebangkrutan sesuai dengan model Altman z-score. Kriteria tersebut yang selanjutnya dijadikan sebagai variabel dependen dalam penelitian ini, yaitu:

a. Jika Z-score $>$ 2,99, maka perusahaan dikategorikan sebagai perusahaan yang sangat sehat sehingga dapat dikategorikan dalam perusahaan tidak bangkrut atau safe (Hanafi, 2008:657).

b. Jika 1,81 < Z-Score < 2,99, artinya perusahaan berada di daerah rawan, dimana perusahaan tersebut tidak dapat ditentukan apakah termasuk perusahaan yang bangkrut atau tidak atau grey area (Hanafi, 2008:657)

c. Jika Z-Score < 1,81, maka dikategorikan sebagai perusahaan yang memiliki kesulitan keuangan yang sangat besar dan beresiko bangkrut atau financial distress (Hanafi, 2008:657)

\subsection{Teknik Analisis Data}

Tehnik analisis data yang digunakan dalam penilitian ini adalah analisis data kuantitatif, yaitu menganalisis data dengan menggunakan perhitungan angka-angka dari laporan keuangan, seperti neraca, laba rugi dan penjualan, yang kemudian digunakan sebagai dasar pengambilan keputusan.

Teknik analisa dalam penelitian ini digunakan untuk menghitung:

1. Rasio keuangan perusahaan dari sampel yang diteliti

2. Data atau hasil perhitungan rasio keuangan kemudian dianalisis dengan menggunakan formula yang ditemukan oleh Altman yaitu:

$Z=1,2(X 1)+1,4(X 2)+3,3(X 3)+0,6(X 4)+1(X 4)$

Keterangan:

X1 = Rasio Modal kerja terhadap total aktiva

X2 = Rasio Laba Ditahan terhadap Total Aktiva

X3 = Rasio Laba Sebelum Bunga dan Pajak terhadap Total Aktiva

X4 = Rasio Nilai Pasar Modal Saham terhadap Nilai Buku Hutang

X5 = Rasio Penjualan terhadap Total Aktiva 


\section{ANALISIS DAN PEMBAHASAN}

\section{Perhitungan Nilai Altman Z-Score dari masing-masing Perusahaan}

1. PT. Indofarma (Persero), Tbk.

Hasil perhitungan nilai Altman Z-Score PT. Indofarma (Persero), Tbk periode 2012-2016 dapat dilihat pada tabel 1 sebagai berikut :

Tabel 1. Nilai Z Score PT. Indofarma (Persero), Tbk tahun 2012 - 2016

\begin{tabular}{|c|c|c|c|c|c|r|l|}
\hline Tahun & $\mathbf{X 1}$ & $\mathbf{X}$ & $\mathbf{X} \mathbf{3}$ & $\mathbf{X} 4$ & $\mathbf{X 5}$ & Altman Z-Score & \multicolumn{1}{|c|}{ Kategori } \\
\hline 2012 & 0.34 & 0.05 & 0.07 & 2.17 & 0.97 & 2.99 & Safe Zone \\
\hline 2013 & 0.14 & 0.00 & $(0.02)$ & 0.67 & 1.03 & 1.52 & Financial Distress \\
\hline 2014 & 0.15 & 1.85 & 0.04 & 5.21 & 1.11 & 7.13 & Safe Zone \\
\hline 2015 & 0.14 & 0.13 & 0.04 & 0.55 & 1.06 & 1.87 & Grey Area \\
\hline 2016 & 0.11 & 0.13 & 0.02 & 1.80 & 1.21 & 2.69 & Grey Area \\
\hline
\end{tabular}

Sumber: hasil olah data laporan keuangan yang diunduh dari www.idx.co.id, 2018

Interpretasi dari data tabel 1 adalah sebagai berikut :

Pada tahun 2012 dan 2014, PT. Indofarma (Persero), Tbk, masuk ke dalam kategori "safe zone", yang artinya bahwa perusahaan tersebut dalam kondisi yang aman dan kinerja keuangannya sehat. Namun pada tahun 2013, PT. Indofarma (Persero), Tbk, mengalami kinerja keuangan yang tidak sehat, sehingga termasuk dalam kategori "financial distress", yang artinya bahwa perusahaan harus memperbaiki kinerja di berbagai aspek, sehingga perusahaan dapat kembali ke posisi aman. Berlanjut pada tahun 2015 dan 2016, perusahaan mengalami kondisi yang masih kurang menguntungkan, yaitu pada posisi grey area, yang artinya bahwa perusahaan dalam kondisi kurang sehat dalam kinerja keuangan, dan diprediksikan rawan mengalami kebangkrutan.

2. PT. Darya-Varia Laboratoria, Tbk

Hasil perhitungan nilai Altman Z-Score PT. Darya-Varia Laboratoria, Tbk periode 20122016 dapat dilihat pada tabel 2 sebagai berikut :

Tabel 2. Nilai Z Score PT. Darya-Varia Laboratoria, Tbk tahun 2012 - 2016

\begin{tabular}{|c|c|c|c|c|c|r|l|}
\hline Tahun & X1 & X2 & X3 & X4 & X5 & Altman Z-Score & \multicolumn{1}{|c|}{ Kategori } \\
\hline 2012 & 0.59 & 0.44 & 0.18 & 3.80 & 1.01 & 5.22 & Safe Zone \\
\hline 2013 & 0.59 & 0.07 & 0.14 & 0.17 & 0.93 & 2.29 & Grey Area \\
\hline 2014 & 0.60 & 0.06 & 0.08 & 1.97 & 0.89 & 3.14 & Safe Zone \\
\hline 2015 & 0.54 & 0.06 & 0.09 & 4.26 & 0.95 & 4.54 & Safe Zone \\
\hline 2016 & 0.45 & 0.05 & 0.13 & 1.75 & 0.95 & 3.05 & Safe Zone \\
\hline
\end{tabular}

Sumber: hasil olah data laporan keuangan yang diunduh dari www.idx.co.id, 2018

Interpretasi dari data tabel 2 adalah sebagai berikut :

PT. Darya-Varia Laboratoria, Tbk secara umum kinerja keuangannya dalam kondisi sehat. Terlihat dari hasil perhitungan dengan menggunakan analisis model Altman zscore, dimana pada tahun 2012, termasuk dalam "safe zone". Namun di tahun 2013, perusahaan masuk dalam kategori grey area, yang berarti bahwa perusahaan sedang mengalami kesulitan keuangan. Kondisi grey area tersebut akhirnya dapat ditangani dengan baik oleh manajemen, sehingga pada tahun 2014, 2015 dan 2016, perusahaan kembali pada kondisi sehat.

3. PT. Kimia Farma (Persero) Tbk.

Hasil perhitungan nilai Altman Z-Score PT. Kimia Farma (Persero), Tbk periode 2012- 
NATHONALLY ACCREDTEO JOURNAL - DECREE NO. 21/E/KPT/2O18

2016 dapat dilihat pada tabel 3 sebagai berikut :

Tabel 3. Nilai Z Score PT. Kimia Farma (Persero), Tbk tahun 2012 - 2016

\begin{tabular}{|c|c|c|c|c|c|r|l|}
\hline Tahun & $\mathbf{X 1}$ & $\mathbf{X} 2$ & $\mathbf{X 3}$ & $\mathbf{X 4}$ & $\mathbf{X 5}$ & Altman Z-Score & \multicolumn{1}{|c|}{ Kategori } \\
\hline 2012 & 0.47 & 0.10 & 0.13 & 1.74 & 1.80 & 3.98 & Safe Zone \\
\hline 2013 & 0.43 & 0.09 & 0.11 & 2.88 & 1.76 & 4.51 & Safe Zone \\
\hline 2014 & 0.40 & 0.08 & 0.12 & 1.72 & 1.52 & 3.53 & Safe Zone \\
\hline 2015 & 0.29 & 0.18 & 0.11 & 3.51 & 1.42 & 4.50 & Safe Zone \\
\hline 2016 & 0.26 & 0.16 & 0.10 & 6.52 & 1.26 & 6.03 & Safe Zone \\
\hline
\end{tabular}

Sumber: hasil olah data laporan keuangan yang diunduh dari www.idx.co.id, 2018

Interpretasi dari data table 3 adalah sebagai berikut :

Dari hasil perhitungan Altman z-score, PT Kimia Farma (Persero), Tbk berada di posisi angka 3.53 - 6.03, termasuk dalam kategori "safe zone". Sehingga dapat disimpulkan bahwa PT Kimia Farma (Persero) pada tahun 2012 sampai dengan 2016 mempunyai kinerja finansial yang stabil dan sehat. Sehingga mempunyai kemungkinan untuk terus meningkatkan kinerjanya. Dampak langsung adalah, kemampuan perusahaan dalam memenuhi segala kewajiban atau liabilitas baik jangka pendek maupun jangka panjang.

4. PT. Kalbe Farma Tbk.

Hasil perhitungan nilai Altman Z-Score PT. Kalbe Farma, Tbk periode 2012-2016 dapat dilihat pada tabel 4 sebagai berikut :

Tabel 4. Nilai Z Score PT. Kalbe Farma, Tbk tahun 2012 - 2016

\begin{tabular}{|c|c|c|c|c|c|r|l|}
\hline Tahun & $\mathbf{X 1}$ & $\mathbf{X} \mathbf{2}$ & $\mathbf{X 3}$ & $\mathbf{X} \mathbf{4}$ & $\mathbf{X 5}$ & Altman Z-Score & \multicolumn{1}{|c|}{ Kategori } \\
\hline 2012 & 0.48 & 0.16 & 0.25 & 39.10 & 1.45 & 26.52 & Safe Zone \\
\hline 2013 & 0.43 & 0.67 & 0.23 & 20.81 & 1.41 & 16.10 & Safe Zone \\
\hline 2014 & 0.46 & 0.71 & 0.68 & 32.90 & 1.40 & 24.94 & Safe Zone \\
\hline 2015 & 0.47 & 0.72 & 0.63 & 27.36 & 1.31 & 21.36 & Safe Zone \\
\hline 2016 & 0.48 & 0.74 & 0.62 & 29.78 & 1.27 & 22.81 & Safe Zone \\
\hline
\end{tabular}

Sumber: hasil olah data laporan keuangan yang diunduh dari www.idx.co.id, 2018

Interpretasi dari data table 4 adalah sebagai berikut :

Pada periode 2012-2016, PT Kalbe Farma, Tbk termasuk dalam kategori "safe zone", yang ditunjukkan dari hasil perhitungan Altman Z-Score dengan angka yang relative sangat tinggi yaitu 26.52 pada tahun 2012 dan angka terendah di angka 16.10 pada tahun 2013.

5. PT. Merck Indonesia, Tbk

Hasil perhitungan nilai Altman Z-Score PT. Merck Indonesia, Tbk periode 2012-2016 dapat dilihat pada tabel 5 sebagai berikut :

Tabel 5. Nilai Z Score PT. Merck Indonesia, Tbk tahun 2012 - 2016

\begin{tabular}{|c|c|c|c|c|c|r|l|}
\hline Tahun & X1 & X2 & X3 & X4 & X5 & Altman Z-Score & Kategori \\
\hline 2012 & 0.60 & 0.66 & 0.25 & 2.89 & 1.63 & 5.84 & Safe Zone \\
\hline 2013 & 0.63 & 0.68 & 0.33 & 2.29 & 1.71 & 5.88 & Safe Zone \\
\hline 2014 & 0.65 & 0.72 & 0.34 & 2.20 & 1.64 & 5.86 & Safe Zone \\
\hline 2015 & 0.05 & 0.74 & 0.29 & 1.81 & 1.53 & 4.66 & Safe Zone \\
\hline 2016 & 0.15 & 0.73 & 0.29 & 2.56 & 1.39 & 5.07 & Safe Zone \\
\hline
\end{tabular}

Sumber: hasil olah data laporan keuangan yang diunduh dari www.idx.co.id, 2018

Interpretasi dari data tabel 5 adalah sebagai berikut :

Pada periode 2012-2016, PT Merck Indonesia, Tbk termasuk dalam kategori "safe zone", jmm.unram.ac.id 
yang ditunjukkan dari hasil perhitungan Altman Z-Score dengan angka 4.66 sampai dengan 5.88.

6. PT. Pyridam Farma, Tbk

Hasil perhitungan nilai Altman Z-Score PT. Pyridam Farma, Tbk periode 2012-2016 dapat dilihat pada tabel 6 sebagai berikut :

Tabel 6. Nilai Z Score PT. Pyridam Farma, Tbk tahun 2012 - 2016

\begin{tabular}{|c|c|c|c|r|r|r|l|}
\hline Tahun & X1 & X2 & X3 & \multicolumn{1}{|c|}{ X4 } & \multicolumn{1}{|c|}{ X5 } & Altman Z-Score & \multicolumn{1}{|c|}{ Kategori } \\
\hline 2012 & 0.30 & 0.24 & 0.66 & 7.06 & 1.30 & 8.39 & Safe Zone \\
\hline 2013 & 0.15 & 0.22 & 0.56 & 4.50 & 1.10 & 6.12 & Safe Zone \\
\hline 2014 & 0.17 & 0.24 & 0.43 & 9.55 & 1.29 & 8.97 & Safe Zone \\
\hline 2015 & 0.23 & 0.29 & 0.06 & 18.05 & 1.36 & 13.07 & Safe Zone \\
\hline 2016 & 0.27 & 0.30 & 0.06 & 17.39 & 1.30 & 12.68 & Safe Zone \\
\hline
\end{tabular}

Sumber: hasil olah data laporan keuangan yang diunduh dari www.idx.co.id, 2018

Interpretasi dari data tabel 6 adalah sebagai berikut :

Pada periode 2012-2016, PT Pyridam Farma, Tbk termasuk dalam kategori "safe zone", yang ditunjukkan dari hasil perhitungan Altman Z-Score dengan angka 6.12 sampai dengan 13.07.

7. PT. Merck Sharp Dohme Pharma, Tbk

Hasil perhitungan nilai Altman Z-Score PT. Merck Sharp Dohme Pharma, Tbk periode 2012-2016 dapat dilihat pada tabel 7 sebagai berikut :

Tabel 7. Nilai Z Score PT. Merck Sharp Dohme Pharma, Tbk tahun 2012-2016

\begin{tabular}{|c|c|c|c|c|c|r|l|}
\hline Tahun & $\mathbf{X 1}$ & $\mathbf{X 2}$ & $\mathbf{X 3}$ & $\mathbf{X 4}$ & $\mathbf{X 5}$ & Altman Z-Score & \multicolumn{1}{|c|}{ Kategori } \\
\hline 2012 & 0.61 & 0.60 & 0.59 & 3.40 & 0.98 & 6.52 & Safe Zone \\
\hline 2013 & 0.62 & 0.61 & 0.62 & 4.20 & 1.01 & 7.19 & Safe Zone \\
\hline 2014 & 0.61 & 0.61 & 0.64 & 3.85 & 1.08 & 7.11 & Safe Zone \\
\hline 2015 & 0.57 & 0.57 & 0.64 & 3.15 & 1.11 & 6.58 & Safe Zone \\
\hline 2016 & 0.56 & 0.55 & 0.66 & 3.40 & 1.18 & 6.86 & Safe Zone \\
\hline
\end{tabular}

Sumber : hasil olah data laporan keuangan yang diunduh dari www.idx.co.id, 2018

Interpretasi dari data tabel 7 adalah sebagai berikut :

Pada periode 2012-2016, PT Merck Sharp Dohme Pharma, Tbk termasuk dalam kategori "safe zone", yang ditunjukkan dari hasil perhitungan Altman Z-Score dengan angka 6.58 sampai dengan 7.19 .

8. PT. Industri Jamu dan Farmasi Sido Muncul, Tbk

Hasil perhitungan nilai Altman Z-Score PT. Industri Jamu dan Farmasi Sido Muncul, Tbk periode 2012-2016 dapat dilihat pada tabel 8 sebagai berikut :

Tabel 8. Nilai Z Score PT. Industri Jamu \& Farmasi Sido Muncul, Tbk tahun 2012-2016

\begin{tabular}{|c|c|c|c|c|c|r|l|}
\hline Tahun & X1 & X2 & X3 & X4 & X5 & Altman Z-Score & \multicolumn{1}{|c|}{ Kategori } \\
\hline 2012 & 0.35 & 0.08 & 0.43 & 1.54 & 1.11 & 3.98 & Safe Zone \\
\hline 2013 & 0.69 & 0.14 & 0.33 & 22.82 & 0.80 & 16.63 & Safe Zone \\
\hline 2014 & 0.60 & 0.15 & 0.30 & 46.90 & 0.78 & 30.83 & Safe Zone \\
\hline 2015 & 0.54 & 0.16 & 0.32 & 41.71 & 0.79 & 27.74 & Safe Zone \\
\hline 2016 & 0.53 & 0.16 & 0.36 & 33.95 & 0.86 & 23.27 & Safe Zone \\
\hline
\end{tabular}


Sumber: hasil olah data laporan keuangan yang diunduh dari www.idx.co.id, 2018 Interpretasi dari data tabel 8 adalah sebagai berikut :

Pada periode 2012-2016, PT Industri Jamu dan Farmasi Sido Muncul, Tbk termasuk dalam kategori "safe zone", yang ditunjukkan dari hasil perhitungan Altman Z-Score dengan angka 3.98 sampai dengan 30.83 .

Terdapat peningkatan yang sangat signifikan dari hasil perhitungan z-score dari tahun 2012 sebesar 3.98 menjadi 30.83 pada tahun 2013. Hal ini dikarenakan adanya peningkatan kapitalisasi dari PT Industri dan Farmasi Sido Muncul, Tbk, yaitu dengan diterbitkannya saham perdana go public (IPO) di Bursa Efek Indonesia pada tahun 2013. Selain hal tersebut, dengan adanya tingkat penjualan yang relatif tinggi dan stabil, sehingga sangat signifikan mempengaruhi tingginya rasio penjualan terhadap total aktiva, yang ditunjukkan dari komponen X5.

9. PT. Tempo Scan Pacific, Tbk

Hasil perhitungan nilai Altman Z-Score PT. Tempo Scan Pacific, Tbk periode 2012-2016 dapat dilihat pada tabel 9 sebagai berikut :

Tabel 9. Nilai Z Score PT. Tempo Scan Pacific, Tbk tahun 2012 - 2016

\begin{tabular}{|c|c|c|c|c|c|r|l|}
\hline Tahun & $\mathbf{X 1}$ & $\mathbf{X} \mathbf{2}$ & $\mathbf{X 3}$ & $\mathbf{X} \mathbf{4}$ & $\mathbf{X 5}$ & Altman Z-Score & \multicolumn{1}{|c|}{ Kategori } \\
\hline 2012 & 0.50 & 0.61 & 0.16 & 1.33 & 1.43 & 4.21 & Safe Zone \\
\hline 2013 & 0.49 & 0.58 & 0.14 & 9.48 & 1.27 & 8.81 & Safe Zone \\
\hline 2014 & 0.44 & 0.59 & 0.12 & 8.51 & 1.34 & 8.20 & Safe Zone \\
\hline 2015 & 0.42 & 0.57 & 0.11 & 4.11 & 1.30 & 5.43 & Safe Zone \\
\hline 2016 & 0.41 & 0.59 & 0.11 & 4.04 & 1.39 & 5.48 & Safe Zone \\
\hline
\end{tabular}

Sumber : hasil olah data laporan keuangan yang diunduh dari www.idx.co.id, 2018

Interpretasi dari data tabel 9 adalah sebagai berikut :

Pada periode 2012-2016, PT Tempo Scan Pacific, Tbk termasuk dalam kategori "safe zone", yang ditunjukkan dari hasil perhitungan Altman Z-Score dengan angka 4.21 sampai dengan 8.81. Tingkat penjualan yang tinggi, sangat signifikan mempengaruhi tingginya rasio penjualan terhadap total aktiva, yang ditunjukkan dari komponen X5. Selain itu, perusahaan juga mempunyai kemampuan financial yang sangat kuat dalam menyelesaikan kewajiban-kewajiban jangka panjang, dengan menggunakan asset milik sendiri.

\section{SIMPULAN DAN SARAN}

\subsection{Simpulan}

Berdasarkan hasil perhitungan dari data masing-masing perusahaan dengan menggunakan model Altman Z-Score, dapat disimpulkan bahwa seluruh perusahaan farmasi yang diteliti rata-rata memiliki kinerja keuangan yang baik dan tidak terindikasi mengalami financial distress atau menuju ke arah kebangkrutan. Hasil perhitungan tersebut dapat dilihat pada tabel 10 di bawah ini:

Tabel 10. Rekapitulasi Nilai Z-Score Perusahaan Farmasi Periode 2012-2016

\begin{tabular}{|c|c|c|c|c|c|c|c|c|}
\hline \multirow{2}{*}{ No } & \multirow{2}{*}{ Nama Perusahaan } & \multicolumn{5}{|c|}{ Z-Score } & \multirow{2}{*}{$\begin{array}{c}\text { Rata- } \\
\text { rata }\end{array}$} & \multirow{2}{*}{$\begin{array}{c}\text { Kondisi } \\
\text { Finansial }\end{array}$} \\
\hline & & 2012 & 2013 & 2014 & 2015 & 2016 & & \\
\hline 1 & $\begin{array}{l}\text { PT. Indofarma (Persero), } \\
\text { Tbk }\end{array}$ & 2,99 & 1,52 & 7,13 & 1,87 & 2,69 & 3,24 & Sehat \\
\hline 2 & $\begin{array}{l}\text { PT. Darya-Varia } \\
\text { Laboratoria, Tbk }\end{array}$ & 5,22 & 2,29 & 3,14 & 4,54 & 3,05 & 3,65 & Sehat \\
\hline
\end{tabular}




\begin{tabular}{|c|l|c|c|c|c|c|c|c|}
\hline 3 & $\begin{array}{l}\text { PT. Kimia Farma } \\
\text { (Persero), Tbk }\end{array}$ & 3,98 & 4,51 & 3,53 & 4,50 & 6,03 & 4,51 & Sehat \\
\hline 4 & PT. Kalbe Farma, Tbk & 26,52 & 16,10 & 24,94 & 21,36 & 22,81 & 22,34 & Sehat \\
\hline 5 & PT. Merck Indonesia,Tbk & 5,84 & 5,88 & 5,86 & 4,66 & 5,07 & 5,46 & Sehat \\
\hline 6 & PT. Pyridam Farma, Tbk & 8,39 & 6,12 & 8,97 & 13,07 & 12,68 & 9,84 & Sehat \\
\hline 7 & $\begin{array}{l}\text { PT. Merck Sharp Dohme } \\
\text { Pharma, Tbk }\end{array}$ & 6,52 & 7,19 & 7,11 & 6,58 & 6,86 & 6,85 & Sehat \\
\hline 8 & $\begin{array}{l}\text { PT. Industri Jamu dan } \\
\text { Farmasi Sido Muncul, } \\
\text { Tbk }\end{array}$ & 3,98 & 16,63 & 30,83 & 27,74 & 23,27 & 20,49 & Sehat \\
\hline 9 & $\begin{array}{l}\text { PT. Tempo Scan Pasific, } \\
\text { Tbk }\end{array}$ & 4,21 & 8,81 & 8,20 & 5,43 & 5,48 & 6,42 & Sehat \\
\hline
\end{tabular}

Sumber: hasil olah data laporan keuangan yang diunduh dari www.idx.co.id, 2018

Masing-masing perusahaan yang diteliti memiliki tingkat z-score yang relatif tinggi, bahkan ada yang rata-rata mencapai 20.49, yaitu PT Industri Jamu dan Farmasi Sido Muncul, Tbk, dan tertinggi adalah PT Kalbe Farma, Tbk, dengan nilai rata-rata hasil perhitungan z-score sebesar 22.34. Hal ini disebabkan karena meningkatnya nilai kapitalisasi dari kedua perusahaan tersebut, dan kondisi financial yang relatif stabil.

Kondisi financial tersebut dapat dilihat dari kemampuan perusahaan dalam memenuhi kewajiban-kewajiban jangka panjang dengan modal sendiri, yang ditunjukkan dari tingginya nilai pasar modal terhadap total hutang atau X4 yang diperoleh dari hasil perhitungan olah data Altman Z-score.

\subsection{Saran}

Untuk penelitian selanjutnya, dapat ditambahkan hal-hal sebagai berikut:

1. Menentukan indikator pendukung lainnya (misalnya intellectual capital, struktur modal, dan lainnya) dalam penentuan posisi apakah perusahaan tersebut diindikasikan akan mengalami financial distress atau tidak.

2. Perusahaan yang diteliti diambil dari beberapa sektor, misal; manufaktur, telekomunikasi, dan sektor lainnya, sehingga dapat dilihat perbandingan dari masingmasing sektor mengenai tingkat kesehatan perusahaan.

\section{DAFTAR PUSTAKA}

Adnan, K. M. dan E. Kurnayasih. (2000). Analisis Tingkat Kesehatan Perusahaan untuk Memprediksi Potensi Kebangkrutan pada Pendekatan Altman. Jurnal Akuntansi dan auditing Indonesia 4(2): 131-149.

Altman, Edward L. dan Hotchkiss, Edith S. (2006). Corporate Financial Distress and Bankruptcy. Edisi ketiga. New Jersey: Wiley.

Anandasayanan.S, Subramaniam V.A, (2017). Predicting Bankruptcy Of Selected Manufacturing Companies Listed In Colombo Stock Exchange: Applying Altman's ZScore. International Journal of Research-Granthaalayah, 5(2), 313-321

Bank Mandiri, PT. (2016). Farmasi. Office of Chief Economist PT Bank Mandiri, Tbk. Industry Update vol.5-2016. mandiri-institute.id.

Brigham, Eugene F. dan Ehrhardt, Michael C. (2014). Financial Management: Theory and Practice. Edisi Keempat Belas. Mason: Cengage Learning.

Bursa Efek Indonesia (2018). Perusahaan Tercatat: Laporan Keuangan dan Tahunan Konsolidasian. http:/ / www.idx.co.id. Jakarta. [diakses pada tanggal 1 Maret 2018].

GP Farmasi, (2018). Bisnis obat 2018 masih tumbuh positif. 
http://industri.kontan.co.id/news/gp-farmasi-bisnis-obat-2018-masih-tumbuh-positif. [diakses tanggal 4 Maret 2018].

Hanafi, M. M. dan A. Halim. (2005). Analisis Laporan Keuangan. AMP-YKPN. Yogyakarta.

Hanafi, M. M. (2008). Manajemen Keuangan. Edisi kesatu. BPFE-Yogyakarta. Yogyakarta.

Hanafi, Mamduh M. (2014). Manajemen Keuangan. Cetakan ke-7. Yogyakarta : BPFE.

Katarina Intan Afni Patunrui, Sri Yati. (2017). Analisis Penilaian Financial Distress Menggunakan Model Altman (Z-Score) Pada Perusahaan Farmasi Yang Terdaftar di Bursa Efek Indonesia Periode 2013-2015. Jurnal Akuntansi, Ekonomi dan Manajemen Bisnis, Vol. 5 No. 1, July 2017, 55-71.

Koran Sindo, (2018). 90\% Bahan Obat Impor, Pemerintah Genjot Investasi Bidang Farmasi. https://ekbis.sindonews.com/read/1285738/34/90-bahan-obat-impor-pemerintah-genjot-investasibidang-farmasi-1519791594. [diakses tanggal 4 Maret 2018].

Muchlisin Riadi: Metode Altman z-score. https://www.kajianpustaka.com/2013/03/metodealtman-z-score.html. [diakses tanggal 3 Maret 2018].

Porter, M. E. (2008). Competitive Advantage: Creating and Sustaining Superior Performance. New York, NY: Free Press.

Rico Chrisnawan, Norita, (2017). Bankruptcy Prediction Analyze Using Altman Z-Score, Grover, And Fulmer In Plantation Sub-Sector Industry Listed In Indonesia Stock Exchange (Case Study On Crude Palm Oil Plantation Period Of 2011-2015). e-Proceeding of Management : Vol.4, No.1 April 2017: 346-353

Rudianto (2013). Akuntansi Manajemen Informasi untuk Pengambilan Keputusan Strategis. Erlangga. Jakarta

Sartono, Agus. (2012). Manajemen Keuangan dan Teori Aplikasi. Edisi keempat. Yogyakarta, BPFE.

S. Christina Sheela, K. Karthikeyan, (2012). Evaluating Financial Health Of Pharmaceutical Industry In India Through 'Z' Score Model. International Journal Of Social Sciences $\mathcal{E}$ Interdisciplinary Research Vol.1 No. 5, May 2012, ISSN 2277 3630: 25-31

Sekaran, Uma. (2006). Metodologi Penelitian untuk Bisnis, Buku 1, Edisi 4. Salemba. Jakarta. Sugiyono. (2010). Metode Penelitian Bisnis. Cetakan ketiga. Alfabeta. Bandung.

Toto, Prihadi. (2011). Analisis Laporan Keuangan Teori dan Aplikasi. Jakarta: PPM. 